\title{
Pro-labour myometrial gene expression: are preterm labour and term labour the same?
}

\author{
Mark Tattersall, Neelam Engineer, Shirin Khanjani, Suren R Sooranna, Victoria H Roberts ${ }^{1}$, \\ Peta L Grigsby ${ }^{1}$, Zhiqing Liang ${ }^{2}$, Les Myatt ${ }^{1}$ and Mark R Johnson
}

Imperial College Parturition Research Group, Department of Maternal Fetal Medicine, Imperial College School of Medicine, Chelsea and Westminster Hospital, 369 Fulham Road, London SW10 9NH, UK, ${ }^{1}$ Department of Obstetrics and Gynecology, University of Cincinnati College of Medicine, 21 Bethesda Avenue, Cincinnati, Ohio 45267, USA and ${ }^{2}$ Department of Obstetrics and Gynaecology, Southwest Hospital, Third Military Medical University, Chonqing 400038, China

Correspondence should be addressed to M R Johnson; Email: mark.johnson@imperial.ac.uk

$M$ Tattersall and $N$ Engineer contributed equally to this work

\begin{abstract}
Preterm labour (PTL) is the most important cause of neonatal morbidity and mortality. While some causes have been identified, the mechanisms involved remain elusive. This study investigates whether term labour (TL) is an appropriate model for PTL by examining prolabour gene expression, using quantitative rtPCR, and protein synthesis, using Western analysis, in preterm and term myometrial samples obtained from the upper and lower uterine segments before and after the onset of labour. In the lower segment, the levels of prostaglandin H synthase type-2 (PGHS-2), interleukin-1 $\beta$ (IL-1 $\beta), I L-6$ and IL-8 mRNA expression were significantly higher in TL compared with PTL samples. Compared with non-labour controls, the expression of $I L-1 \beta$ and $I L-8$ mRNA was increased in both PTL and TL samples and the expression of PGHS-2 and IL-6 mRNA was increased in TL samples only. In the upper segment, there were no differences between PTL and TL samples and the mRNA expression of PGHS-2 and IL-1 $\beta$ was increased in TL compared with term no labour samples. No effect of PTL or TL was seen on either oxytocin receptor or connexin-43 mRNA expression or protein levels. The multiple regression analysis and studies in primary cultures of uterine myocytes suggest that the inflammatory cytokines, IL-1 $\beta$ and tumour necrosis factor- $\alpha$, are the most important regulators of PGHS-2 and IL-8. Our data show that preterm and term labouring myometrium are significantly different and that the most marked labour-induced changes in gene expression are in the lower segment. These changes may occur in response to the release of inflammatory cytokines by the labour-associated inflammatory infiltration. Reproduction (2008) 135 569-579
\end{abstract}

\section{Introduction}

Preterm labour (PTL), particularly before 32 weeks, is associated with a high fetal morbidity and mortality and consequently is the subject of intense research with the aim of devising preventative or therapeutic strategies. One approach has been to define what triggers term labour (TL) and key roles have been ascribed to the oxytocin receptor (OXTR) and connexin-43 (CX-43). However, more recently, the importance of prostaglandins (PG) and inflammatory cytokines in the process has been realised.

Early studies reported that myometrial OXTR levels are low in early pregnancy, increase with advancing gestation, peak in early labour and decline in advanced labour (Fuchs et al. 1984). Other studies suggested that OXTR expression increases with gestational age rather than with the onset of labour (Kimura et al. 1996, Wathes et al. 1999), but more recently OXTR mRNA expression was reported to increase with the onset of TL (Mesiano et al. 2002, Terzidou et al. 2005). CX-43 is also thought to play a critical role in the onset of labour by increasing myometrial cell coupling. In the rat, a small increase in $C x-43$ mRNA and protein levels occurs prior to the onset of labour and a marked increase during labour itself (Risek et al. 1990, Lye et al. 1993, Ou et al. 1997). In the human, Sparey et al. (1999) found that CX-43 protein was significantly increased in labouring samples and that this was most marked in the upper segment (US) of the uterus.

There is a massive influx of macrophages, neutrophils and T-lymphocytes into the myometrium and gestational tissues with labour (Thomson et al. 1999, Keski-Nisula et al. 2000). The activated leucocytes express proinflammatory cytokines increasing myometrial levels of interleukin (IL)-1 $\beta$ and IL-8 (Osmers et al. 1995, Winkler et al. 1999, Osman et al. 2003). The latter promotes 
further neutrophil infiltration and activation, and the former stimulates PG production. PG production is increased in fetal membranes and myometrium with labour (Turnbull et al. 1977, Skinner \& Challis 1985) resulting in increased circulating and amniotic fluid PG levels (Sellers et al. 1981, Brennecke et al. 1985, Romero et al. 1994). Consistent with these observations, labour is associated with increased myometrial levels of $\mathrm{PGH}$ synthase type-2 (PGHS-2) mRNA and protein (Mesiano et al. 2002, Sooranna et al. 2004). Increased PG levels act on the myometrium to increase uterine contractility and so promote the onset and progression of labour.

In this study, we have tested the hypothesis that there is no difference in myometrial pro-labour gene expression in PTL and TL samples. To achieve this, we have examined the mRNA expression of a group of pro-labour genes, OXTR, CX-43,IL-8 and PGHS-2 and related the pro-labour gene expression to those of the proinflammatory cytokines IL-1 $\beta$, IL- 6 and tumour necrosis factor- $\alpha$ (TNF- $\alpha$ ) in preterm and term myometrial samples obtained from the upper and lower uterine segments before and after the onset of labour.

\section{Results}

\section{Gene expression}

PTL versus $T L$

In the lower segment, the expression of IL-8, PGHS-2, $I L-1 \beta$ and IL- 6 mRNA was greater in TL samples than in PTL samples $(P<0.01$ for $I L-8$ and $P G H S-2$, and $P<0.05$ for $I L-1 \beta$ and $I L-6$; Fig. $1 A, B, E$ and $F)$. There were no significant differences in the US samples for OXTR, IL-8, PGHS-2, CX-43, IL-1 $\beta, I L-6$ and TNF- $\alpha$ mRNA expression (Fig. 1A-G).

\section{Non-labour versus labour}

In the lower segment PTL samples, $I L-8$ and $I L-1 \beta$ mRNA expression was increased compared with preterm no labour (PTNL) lower segment samples (both $P<0.05$; Fig. $1 \mathrm{~A}$ and $\mathrm{E})$. There were no significant differences in the US samples. In TL lower segment samples, the expression of $I L-8, P G H S-2, I L-1 \beta$ and $I L-6$ mRNA was increased compared with term no labour (TNL) samples $(P<0.01$ for $I L-8, I L-6$ and $P G H S-2$ and $P<0.05$ for
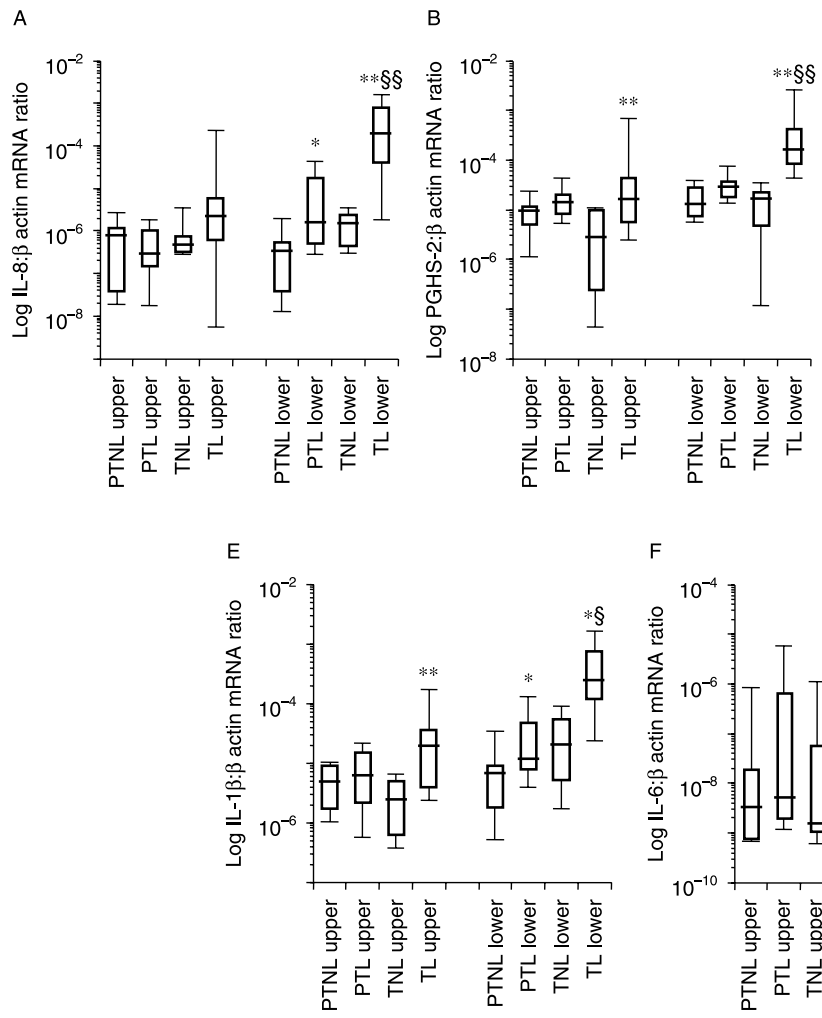

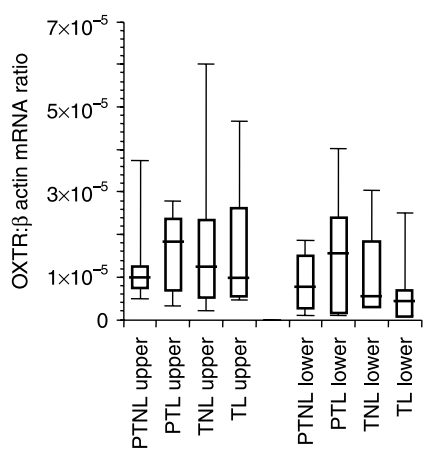

D

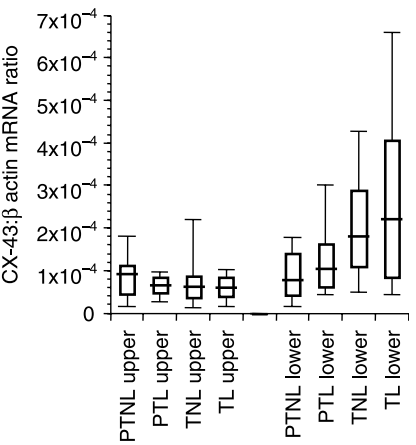

F

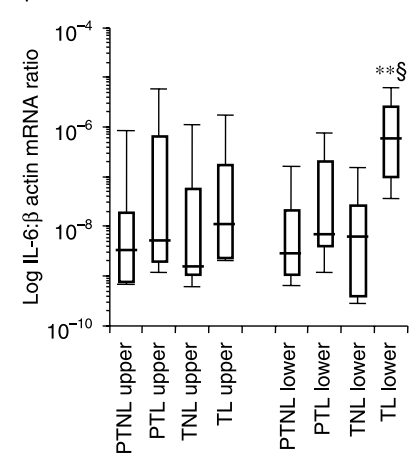

G

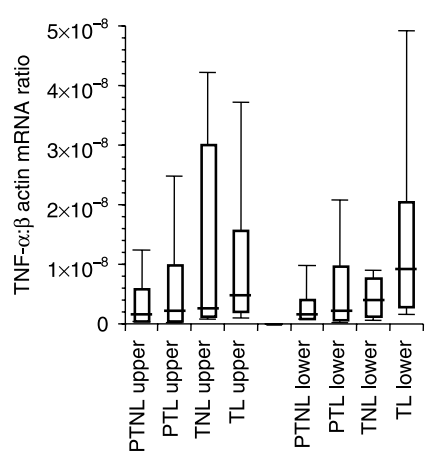

Figure 1 (A) Interleukin-8 (IL-8), (B) prostaglandin H synthase-2 (PGHS-2), (C) oxytocin receptor $(O X T R),(\mathrm{D})$ connexin-43 (CX-43), (E) IL-1 $\beta,(\mathrm{F}) I L-6$ and $(G)$ tumour necrosis factor- $\alpha(T N F-\alpha)$ : $\beta$-actin mRNA ratio (median, interquartile range and range) in paired upper and lower human myometrial samples obtained from the following four groups of women: at the time of caesarean section (LSCS) under the conditions of preterm with labour (PTL; $33.9 \pm 1.5$ weeks, $n=9$ ), preterm no labour (PTNL; $30.4 \pm 1.5$ weeks, $n=9$ ), term with labour (TL; $39.2 \pm 0.5$ weeks, $n=10)$ and term no labour (TNL; 38.4 \pm 0.4 weeks, $n=8$ ). *A difference of $P<0.05$ and **a difference of $P<0.01 ;{ }^{\S}$ a difference of $P<0.05$ and ${ }^{\S \S}$ a difference of $P<0.01$ in term labour compared with preterm labour samples and * a difference of $P<0.05$ and $\#$ a difference of $P<0.01$ in the upper segment compared with the lower segment samples. 
IL-1 $\beta$; Fig. $1 \mathrm{~A}, \mathrm{~B}, \mathrm{E}$ and $\mathrm{F})$; and in the US samples, the expression of $P G H S-2$ and $I L-1 \beta$ mRNA was increased in TL compared with TNL samples (both $P<0.01$; Fig. 1B and E).

\section{Upper versus lower segment}

In paired US and lower segment samples (preterm and term, non-labour and labour), the expression of $I L-8$, PGHS-2, IL-1 $\beta$ and $C X-43$ mRNA was greater in the lower segment samples than in the US samples $(P<0.0001$ for $P G H S-2$ and $I L-1 \beta$ and $P<0.01$ for IL-8 and CX-43; Fig. $1 \mathrm{~A}, \mathrm{~B}, \mathrm{D}$ and E). OXTR mRNA expression was greater in the US than in the lower segment samples $(P=0.025$, Fig. $1 \mathrm{C})$.

\section{Western blotting for protein concentration}

Western analysis for PGHS-2, OXTR (both antibodies) and CX-43 confirmed the mRNA data (Fig. 2A-D). The similarity in the phospho-CX-43 suggests that there is no change in activity (Fig. 2E). The expression of PGHS-2 protein was greater in TL lower segment samples compared with TNL lower segment samples $(P<0.05$, Fig. 2A). The levels of $\mathrm{CX}-43$ tended to be greater in the lower segment and OXTR (detected with the C-terminus antibody) tended to be greater in the US. No differences in PGHS-2 were apparent.

\section{Gestational age}

In order to identify changes in gene expression that may occur with advancing gestation and prior to the onset of labour and which may therefore have a role in the onset of labour, we performed a Spearman test for non-parametric data looking for associations between gestational age and mRNA expression in the non-labour samples $(n=17)$. In the lower segment, $C X-43$ mRNA expression was associated with gestational age $(r=0.58, \quad P=0.014)$ and $I L-8$ mRNA expression was also weakly associated $(r=0.47$, $P=0.055)$. In the US, PGHS-2 mRNA expression was negatively associated with gestational age $(r=-0.55$, $P=0.023)$. There was no association between gestational age and OXTR mRNA expression in either lower or US samples.

\section{Multiple regression analysis}

Multiple regression analysis for OXTR, CX-43, PGHS-2 and $I L-8$ was performed including $O X T R, I L-8, C X-43$, $P G H S-2, I L-1 \beta, T N F-\alpha$ and $I L-6$ mRNA levels, gestational age, sample site and labour status. For PGHS-2, the resulting equation could explain $60 \%\left(r^{2}, P<0.0001\right)$ of the variance in its levels, for $I L-8,77 \%\left(r^{2}, P<0.0001\right)$, for OXTR, $19 \%\left(r^{2}, P=0.13\right)$ and for $C X-43,70 \%$ $\left(r^{2}, P<0.0001\right.$, Table 1).
A

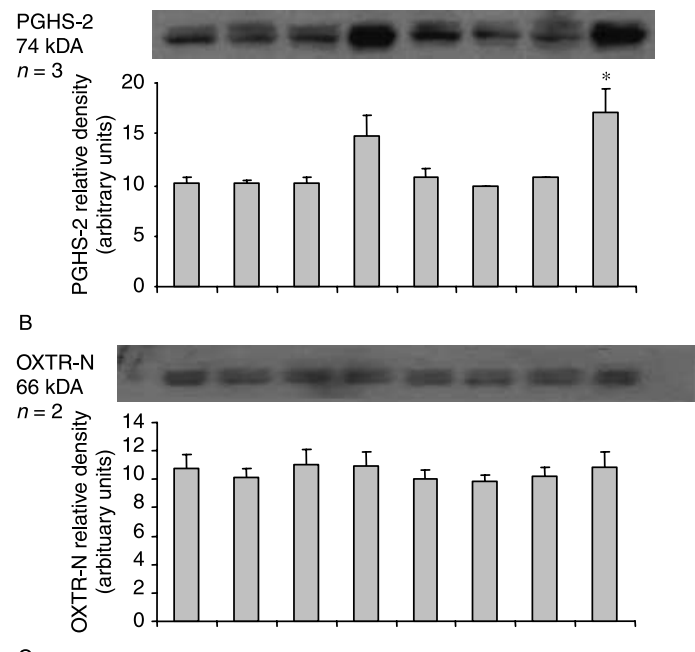

C
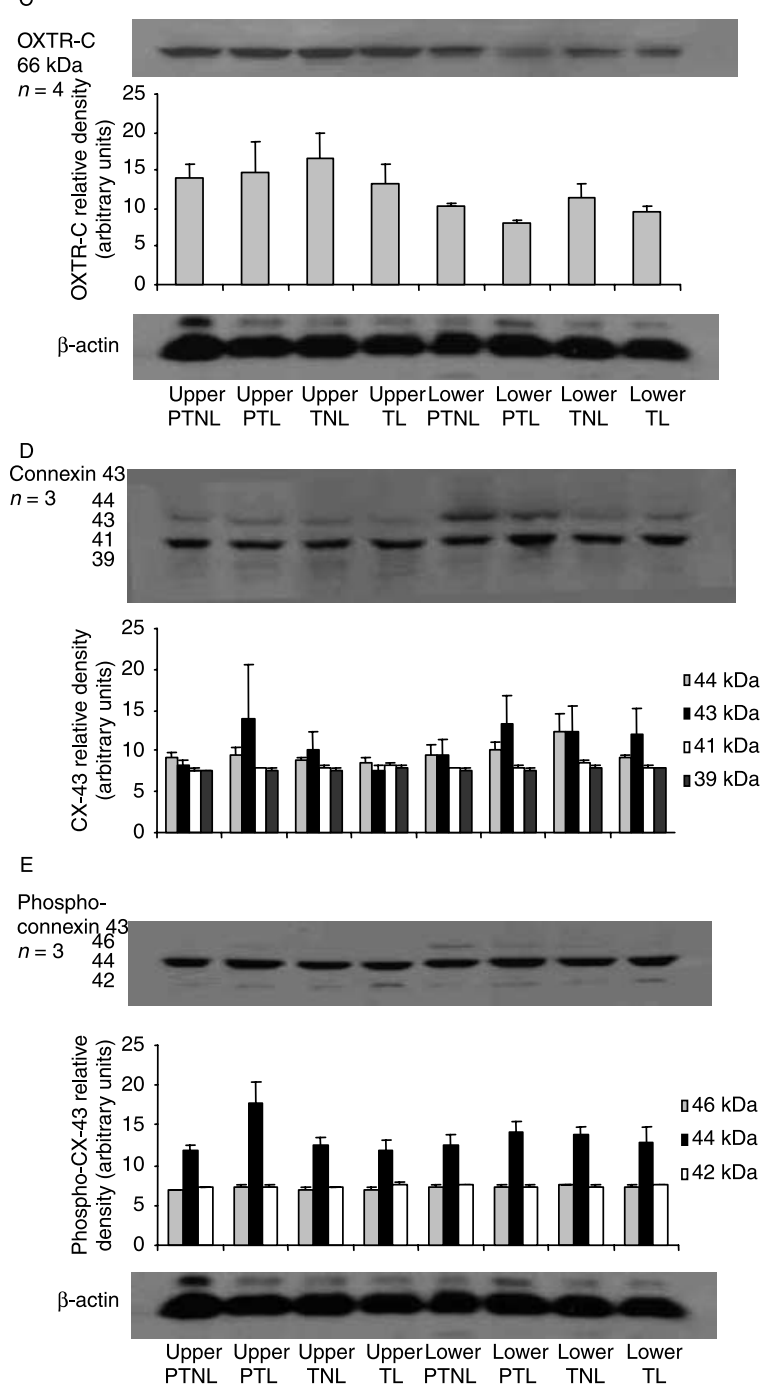

Figure 2 (A) Western analysis of prostaglandin $\mathrm{H}$ synthase-2 (PGHS-2), (B) oxytocin receptor (OXTR, antibody directed to the N-terminus), (C) OXTR (antibody directed to the C-terminus), (D) connexin-43 $(\mathrm{CX}-43)$ and (E) phospho-CX-43. ${ }^{*}$ A difference of $P<0.05$ in labour compared with non-labour samples. 
Table 1 The multiple regression analysis for oxytocin receptor (OXTR), connexin-43 (CX-43), prostaglandin $\mathrm{H}$ synthase type-2 (PGHS-2) and interleukin-8 (IL-8). The analysis was performed including OXTR, IL-8, $C X-43, P G H S-2 I L-1 \beta$, tumour necrosis factor- $\alpha(T N F-\alpha)$ and IL-6 mRNA levels, gestational age, sample site and labour status.

\begin{tabular}{|c|c|c|}
\hline $\begin{array}{l}\text { Pro-labour gene } \\
\left(r^{2} \text { and } P \text { value }\right)\end{array}$ & Related factor & $\boldsymbol{t}$ value ( $P$ value $)$ \\
\hline \multirow{4}{*}{$\begin{array}{l}\text { PGHS-2 (60\%, } \\
P<0.0001)\end{array}$} & IL-8 & $3.54(P=0.0008$ \\
\hline & IL-6 & $4.26(P<0.0001)$ \\
\hline & CX-43 & $2.63(P=0.01)$ \\
\hline & IL-1 $\beta$ & $2.09(P=0.04)$ \\
\hline \multirow{2}{*}{$\operatorname{OXTR}(19 \%, P=0.13)$} & Upper or lower segment & $2.24(P=0.03)$ \\
\hline & IL-6 & $2.18(P=0.03)$ \\
\hline \multirow{4}{*}{$\begin{array}{l}\text { CX-43 (70\%, } \\
P<0.0001)\end{array}$} & PGHS-2 & $2.68(P=0.01)$ \\
\hline & IL-1 $\beta$ & $3.13(P=0.003)$ \\
\hline & TNF- $\alpha$ & $2.59(P=0.01)$ \\
\hline & Upper or lower segment & $3.71(P=0.0004$ \\
\hline \multirow[t]{3}{*}{ IL-8 $(77 \%, P<0.0001)$} & PGHS-2 & $3.54(P=0.0008$ \\
\hline & IL-1 $\beta$ & $7.68(P<0.0001)$ \\
\hline & IL-6 & $2.03(P=0.047)$ \\
\hline
\end{tabular}

\section{Cell culture}

We studied the time course of the effects of TNF- $\alpha$, IL-1 $\beta$, IL- 6 and IL- 8 on IL-8, PGHS-2, OXTR and CX-43 mRNA expression (Fig. 3A-D). The mRNA expression of $I L-8$ was increased by IL-1 $\beta$ (at 1,6 and $24 \mathrm{~h}, P<0.05$ ), TNF- $\alpha$ (at 1 , 6 and $24 \mathrm{~h}, P<0.05$ ) and IL-8 (at $24 \mathrm{~h}, P<0.05$ ); of $P G H S-2$ was increased by IL-1 $\beta$ (at 1,6 and $24 \mathrm{~h}, P<0.05$, TNF- $\alpha$ (at 1,6 and $24 \mathrm{~h}, P<0.05$ ), IL-6 (at $24 \mathrm{~h}, P<0.05$ ) and IL-8 (at $24 \mathrm{~h}, P<0.05$ ); of OXTR was reduced by IL-1 $\beta$ (at 6 and $24 \mathrm{~h}, P<0.05$ ) and of $C X-43$ was increased by TNF- $\alpha$ (at 6 and 24 h, $P<0.05$; Fig. 3A-D).

We then studied the time course of the effects of the prolabour factors $\mathrm{PGE}_{2}(10 \mathrm{nM}), \mathrm{PGF}_{2 \alpha}(10 \mathrm{nM})$ and OXT (100 nM) on IL-8, PGHS-2, OXTR and CX-43 mRNA expression (Fig. 4A-D). The mRNA expression of $I L-8$ was increased by $\mathrm{PGE}_{2}$ at $1 \mathrm{~h}(P<0.05)$ and $\mathrm{OXT}$ at $1 \mathrm{~h}$ $(P<0.05)$ and then reduced by OXT at $24 \mathrm{~h}(P<0.05)$; of $P G H S-2$ was increased by $\mathrm{PGE}_{2}$ (at $1 \mathrm{~h}, P<0.05$ ) and OXT (at 1 and $6 \mathrm{~h}, P<0.05$ ); of $O X T R$ was reduced by $\mathrm{PGE}_{2}$ (at 6 and $24 \mathrm{~h}, P<0.05$ ) and OXT (at 6 and $24 \mathrm{~h}, P<0.05$ ) and of $C X-43$ unaffected (Fig. 4A-D).
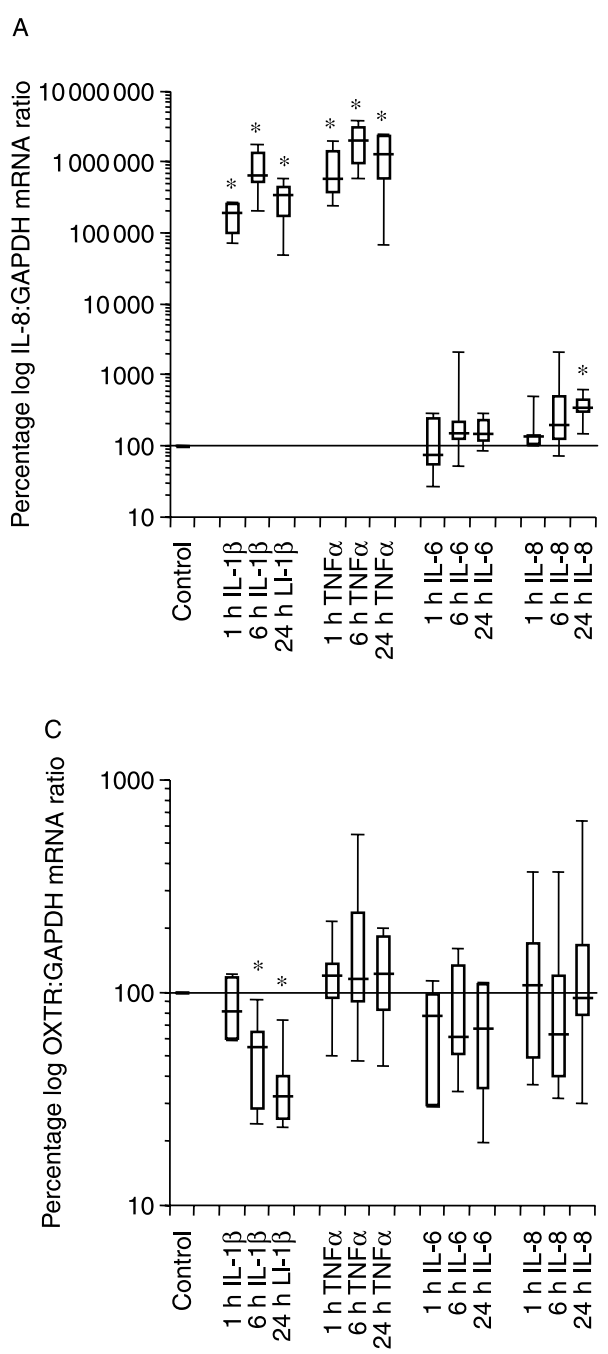

Reproduction (2008) 135 569-579
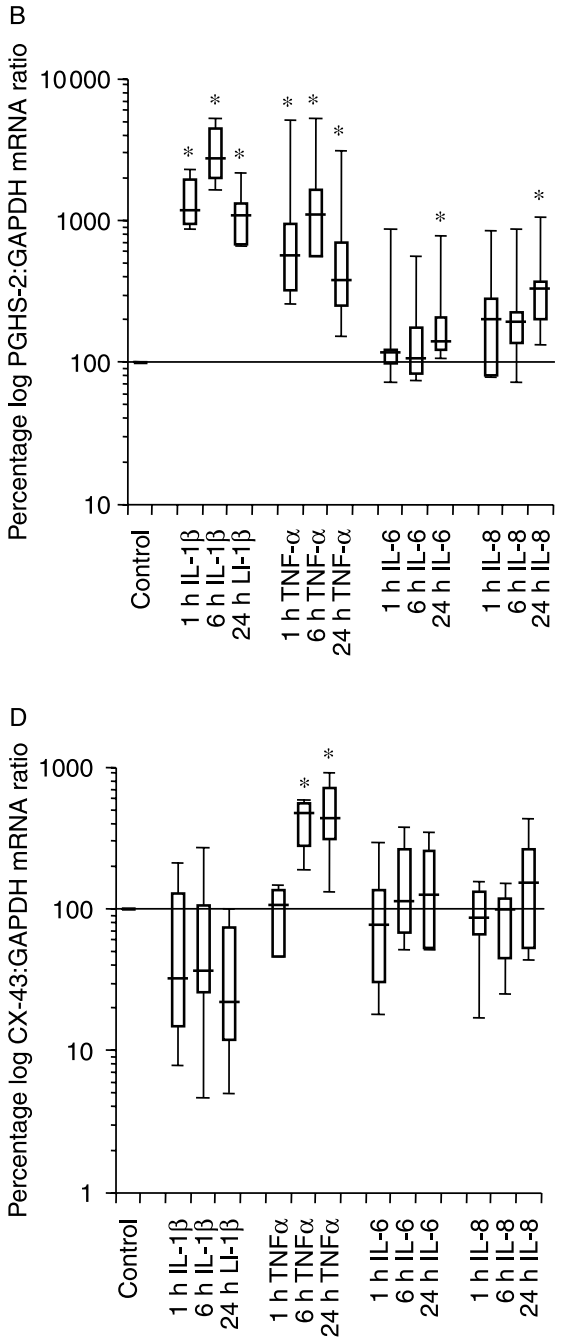

Figure 3 The response of $(A)$ interleukin-8 $(I L-8)$, (B) prostaglandin $\mathrm{H}$ synthase-2 (PGHS-2), (C) oxytocin receptor (OXTR), (D) connexin-43 (CX-43):GAPDH mRNA ratio (median, interquartile range and range) in primary cultures of human uterine smooth muscle cells to incubation for $0,1,6$ and 24 h with IL-1 $\beta 1 \mathrm{ng} / \mathrm{ml}), \mathrm{TNF}-\alpha 1 \mathrm{ng} / \mathrm{ml})$, IL-6 $(1 \mathrm{ng} / \mathrm{ml})$, IL-8 $(1 \mathrm{ng} / \mathrm{ml})$ as described in Materials and Methods

( $n=6-12)$. *A difference of $P<0.05$. 

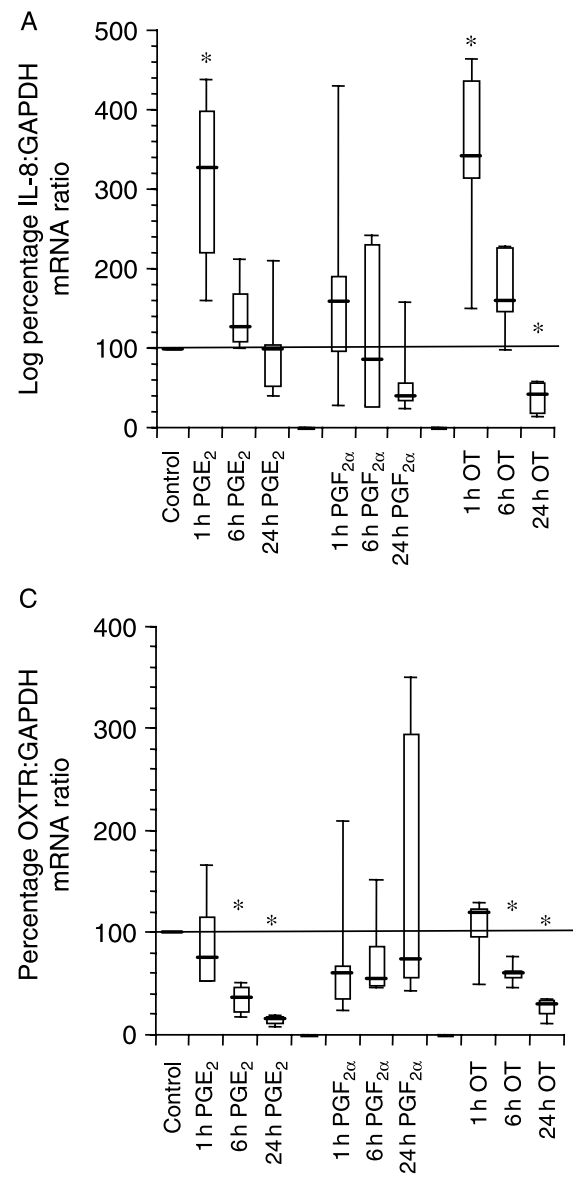

\section{Discussion}

This study shows that pro-labour gene expression is different in term and preterm myometrial samples and that of the prolabour genes studied only PGHS-2 and IL-8 were significantly elevated with the onset of labour and that these changes were most marked in the lower segment. The multiple regression analysis suggested that the pro-labour gene mRNA expression was associated with that of the cytokines and of PGHS-2, while the cell culture data suggested that the most important modulators of pro-labour gene expression were the inflammatory cytokines IL-1 $\beta$ and TNF- $\alpha$. Physiologically, these data imply that the myometrial inflammatory infiltration associated with both preterm and TL is important in the onset and progression of labour.

OXTR mRNA expression is a consistent marker of labour in animal models of parturition (Soloff et al. 1979), has been reported to be increased in human labour by several groups including our own (Mesiano et al. 2002, Terzidou et al. 2005) and used by others to differentiate labouring samples (Condon et al. 2003). However, it is also reported that OXTR mRNA expression does not increase with the onset of labour but with advancing gestation, prior to the onset of labour (Kimura et al. 1996, Wathes et al. 1999). Our data show no increase in OXTR mRNA either with the onset of labour (whether at or before term) or with advancing gestation. Furthermore, our mRNA data are supported by Western analysis of OXTR levels that also show no change. Overall, the evidence suggests that OXTR mRNA expression is increased in some but not all women with the onset of labour, and that perhaps the wellrecognised increase in OXTR sensitivity to OXT (Fuchs et al. 1983) is more important than an increase in OXTR mRNA expression. Our data are consistent with several recent gene array studies that failed to find an increase in OXTR with the onset of labour (Aguan et al. 2000, Charpigny et al. 2003, Esplin et al. 2005, Havelock et al. 2005, Bukowski et al. 2006). Interestingly, the factors we included in the multiple regression analysis accounted for relatively little of the variation in OXTR mRNA expression, suggesting that other factors regulate OXTR mRNA expression during pregnancy. Our in vitro studies found that OXTR mRNA expression was either unchanged or reduced (as reported previously for IL-1 $\beta$ (Schmid et al. 2001, Helmer et al. 2002, Soloff et al. 2006) and OXT (Phaneuf et al. 2000)) in response to cytokines and prolabour factors supporting our myometrial data.

CX-43 is held to have an important role in TL. Animal data consistently show that both mRNA and protein levels of $C X-43$ increase with the onset of labour (Lye 
et al. 1993, McNutt et al. 1994, Ou et al. 1997, Cook et al. 2000) and that ablation of CX-43 delays the onset of parturition (Doring et al. 2006). Human data are less robust, with some studies showing increases in protein alone (Sparey et al. 1999), some in mRNA but not protein (Chow \& Lye 1994, Pierce et al. 2002) and some no change in mRNA (Rezapour et al. 1997). The spatial expression of CX-43 protein was assessed in one study and found to be greater in the US in both non-labour and labour samples (Sparey et al. 1999). Two studies suggested that failure to progress in labour was associated with lower levels of $C X-43$ mRNA expression (Pierce et al. 2002, Cluff et al. 2006). We found that CX-43 mRNA expression, protein levels and phosphorylation status were unchanged with either term or PTL. Furthermore, several studies have been performed using differential display or gene arrays and none have mentioned $C X-43$, either because it was unchanged or because it was not included in the array (Aguan et al. 2000, Chan et al. 2002, Charpigny et al. 2003, Esplin et al. 2005, Havelock et al. 2005, Bukowski et al. 2006). Our multiple regression studies found associations between the mRNA levels of $C X-43$ and those of $I L-1 \beta$, $T N F-\alpha$ and $P G H S-2$, but the in vitro data found that only TNF- $\alpha$ affected $C X-43$ mRNA expression. Overall, these data suggest that in the human at least $C X-43$ is not consistently up-regulated with the onset of labour.

The expression of PGHS-2 mRNA was increased in both the upper and lower uterine segments with $T L$, but not PTL, and there was no increase with gestational age in either segment. The term data are consistent with most recent reports (Mesiano etal. 2002, Sooranna et al. 2004), but contrast with our previous observations and the trend reported by Sooranna et al. (2006) and Astle et al. (2007). The mechanism involved in the up-regulation of $P G H S-2$ activity with the onset of labour is uncertain, but several stimuli including IL-1 $\beta$ are known to increase PGHS-2 expression via the transcription factor nuclear factor $\kappa \mathrm{B}$ (NFKB) (Allport et al. 2001). Indeed, most data suggest that inflammatory cytokines increase myometrial contractility via increased PG synthesis (Khatun et al. 1999). The multiple regression data revealed associations between the levels of PGHS-2 mRNA and those of IL-8, $I L-6$ and $I L-1 \beta$ and our in vitro studies confirmed the important role played by IL- $1 \beta$; in contrast both IL- 6 and IL-8 had a small effect. Interestingly, TNF- $\alpha$ had a marked stimulatory effect on PGHS-2 mRNA expression, but we found no association between their levels in myometrial samples. OXT is known to activate ERK $1 / 2$ and to increase PGHS-2 in an ERK-dependent manner (Strakova et al. 1998). OXT-induced ERK $1 / 2$ activation may also explain the increase in $I L-8$ mRNA expression observed in response to OXT. These inconsistencies may reflect the difference between the behaviour of uterine myocytes in primary culture as opposed to the in vivo situation where their function is modulated by other cellular and connective tissue components of the myometrium.
We found that IL-8 is increased in both PTL and TL consistent with the published data (Winkler et al. 1999, Elliott et al. 2000, Chan et al. 2002, Osman et al. 2003). The multiple regression analysis found associations between $I L-8$ mRNA levels and those of PGHS-2, IL-1 $\beta$ and $I L-6$, but in vitro, uterine myocyte expression of IL- 8 was increased by IL- $1 \beta$ and TNF- $\alpha$, but not IL- 6 . Interestingly, neither $\mathrm{PGE}_{2}$ nor $\mathrm{PGF}_{2 \alpha}$ affected $I L-8$ mRNA expression significantly, suggesting that the association between $I L-8$ and PGHS-2 mRNA levels seen in the multiple regression analysis may reflect a common regulation of both genes by inflammatory cytokines. We also found that IL-8 increased with advancing gestation in non-labour samples albeit weakly, and previously we found that $I L-8$ mRNA expression and synthesis were increased by mechanical stretch of uterine myocytes in vitro (Loudon et al. 2004). Together, these data suggest that myometrial $I L-8$ mRNA expression may be physiologically up-regulated by increasing uterine wall tension secondary to the growth of the pregnancy. The increased IL-8 synthesis could then provoke an inflammatory infiltration of the myometrium resulting in the release of IL-1 $\beta$ which stimulates further myometrial synthesis of IL-8, so establishing a positive feedback loop culminating in the onset of labour.

It is possible that the differences we found between PTL and TL are the result of confounding factors, but the groups were similar in most respects and particularly in terms of cervical dilatation, gravidity and parity. Some discrepancy is inevitable between groups, for example, the term group it is more likely have an LSCS for failure to progress and less likely to have an LSCS for malpresentation than the PTL group. The causes of PTL were uncertain for the majority, two having multiple pregnancies and one having an abruption with a non-reassuring fetal heart pattern. There were differences in the racial distribution between groups, the TL group contained relatively more African Americans than the PTNL group, but gene expression in these groups was not directly compared. Certainly, in general terms, labour of an infective aetiology would be expected to be over-represented in the PTL group, but such a cause would also be expected to be associated with an overexpression of inflammatory genes. However, in our study, it appeared the converse was true and inflammatory gene expression was lower in PTL. PTL in multiple pregnancies might be expected to overexpress PGHS-2 and $I L-8$ as these are the most consistent stretch-responsive genes (Sooranna et al. 2005); again, this was not the picture we observed. The relatively greater variation in mRNA levels of the genes analysed may have masked significant changes between groups, only a larger study of clinically well-defined cases will allow us to clarify the molecular mechanisms responsible for the onset of PTL of different causes.

The inflammatory cytokines, IL-1 $\beta$, IL- 6 and TNF- $\alpha$ are thought to be released by activated neutrophils and to promote the onset of labour by increasing PGHS-2 
synthesis. We found that the pattern of expression of $I L-1 \beta$ mRNA in myometrial samples was very similar to that of $I L-8$, but $I L-6$ mRNA expression was only increased in TL lower segment samples and $T N F-\alpha$ mRNA expression was not significantly different in any group. Others have reported that lower segment $I L-1 \beta$ and $I L-6$, but not $T N F-\alpha$, mRNA expression is increased with labour (Maul et al. 2002, Osman et al. 2003). Thus, our observation of a lack of change in TNF- $\alpha$ mRNA expression with the onset of labour is consistent with the literature. However, in the mouse model, TNF- $\alpha$ seems to have an important role, since knocking out either IL-1 or TNF receptors alone failed to prevent infectioninduced PTL, but removing both IL- 1 and TNF- $\alpha$ receptors significantly reduces infection-induced PTL (Hirsch et al. 2006). These data imply that the combination of IL-1 and TNF- $\alpha$ plays a critical role in the process of infectioninduced PTL in the mouse. In the primate, intra-amniotic infusions of IL- $1 \beta$ stimulated the most intense contraction pattern, while TNF- $\alpha$ infusions induced labour in two cases and moderate contractions in three others (Sadowsky et al. 2006). The exact roles and relative importance of the inflammatory cytokines in human labour are not certain, but the evidence suggests that they are very likely to be involved in the onset of labour.

In this study, the expression of $I L-8$, PGHS-2, IL-1 $\beta$ and CX-43 mRNA was greater in the lower segment than in their paired US samples; only OXTR mRNA expression was greater in the US than in the lower segment samples. These data are consistent with the literature with regard to OXTR (Blanks et al. 2003), but not for $C X-43$, the expression of which was previously reported to be greater in the US (Sparey et al. 1999). We have previously reported that $C P L A_{2}, s P L A_{2}, P G H S-2, P G E S-1$ and PGES-2 mRNA expression were greater in the lower than in the US samples (Sooranna et al. 2006) in agreement with Sparey et al. (1999) in the case of PGHS-2. Our observation that the mRNA expression of the inflammatory cytokine IL-1 $\beta$ is greater in the lower than in the US is consistent with the more marked inflammatory infiltration found in the lower segment (Thomson et al. 1999). The lower segment starts to form at the end of the second trimester reflecting increased tension in this portion of the uterus. As discussed above, it is possible that the increase tension induces IL-8 production initiating the process that results in the onset of labour. Certainly, the increase in gene expression associated with labour appears to greatest in the lower segment, suggesting that changes in the lower segment drive the process, producing uterotonins that promote the contractile activity of the US.

These data suggest that myometrial gene expression is different in PTL and TL. Clearly, PTL occurs for many reasons, such as infection, ruptured membranes and cervical insufficiency, and our approach to compare all cases of PTL to TL does not allow us to discriminate. Furthermore, we have only analysed genes directly related to labour or inflammation and other sets of genes may behave differently. Only by studying accurately phenotyped samples obtained from women in PTL will we be able to define whether some subsets of PTL are in fact accelerated TL while other types of PTL are distinct from TL.

\section{Materials and Methods}

\section{Tissue collection and preparation}

All procedures involving human myometrial tissues were conducted in compliance with the Institution Review Board of the University of Cincinnati (Cincinnati, OH, USA). Informed consent was obtained from all women prior to any tissue collection. Paired upper and lower segment human myometrial samples were obtained from the following four groups of women (mean gestational age \pm s.D. in each case): at PTNL (31.5 \pm 3.5 weeks; mean \pm s.D.; $n=9)$, PTL (32.3 \pm 4.1 weeks; $n=9)$, TNL (38.0 \pm 1.2 weeks; $n=8)$ and TL (39.4 \pm 0.5 weeks; $n=10$; Table 2). Labour was defined as the presence of regular uterine contractions (every 3-4 min) resulting in cervical effacement and dilation. Myometrial samples were removed from the upper margin of the incision made in the lower uterine segment and for the US, an Allis clamp was used to group a small segment $(1.0 \times 0.5 \mathrm{~cm})$ of myometrium below the fundus and tissue excised using Mayo scissors (this included the serosal surface but not the endometrium). Homeostasis was obtained using a single figure of size 8 suture. Tissues were flash frozen in liquid nitrogen prior to storage at $-80^{\circ} \mathrm{C}$. The indications for caesarean section included: failure to progress $(n=4)$, fetal distress $(n=8)$, previous uterine surgery $(n=12)$, malpresentation $(n=5)$, severe pre-eclampsia $(n=5)$, placenta praevia $(n=1)$ and gestational diabetes $(n=1)$.

\section{Quantitative RT-PCR}

Total RNA was extracted and purified from the upper and lower segment myometrial samples using the Tri-reagent method (Trizol, Sigma-Aldrich Co. Ltd). After quantification, $2.0 \mu \mathrm{g}$ RNA was pretreated with DNase I (Amp Grade, Invitrogen Ltd) and then reverse transcribed with Oligo dT random primers using SuperScript II reverse transcriptase (Invitrogen Ltd). Total RNA was extracted and purified from myometrial cells grown on 6-well plates using the RNAeasy mini kit from Qiagen Ltd. After quantification, $1.0 \mu \mathrm{g}$ was reverse transcribed with oligo dT random primers using MuLV reverse transcriptase (Applied Biosystems Ltd, Warrington, UK).

Paired oligonucleotide primers for amplification of prolabour genes were designed using Primer Designer (Scientific and Educational Software, Durham, NC, USA) against the sequence downloaded from GenBank. The primer sets used (Table 3) produced amplicons of the expected size and flanked intron/exon junctions. Assays were validated for all primer sets by confirming that single amplicons of appropriate size and sequence were generated. Quantitative PCR was performed in the presence of SYBR Green (Qiagen Ltd), and amplicon yield was monitored during cycling in a RotorGene Sequence Detector (Corbett Research Ltd, Mortlake, Sydney, Australia). Pre-PCR cycle was $10 \mathrm{~min}$ at $95^{\circ} \mathrm{C}$ followed by up to 45 cycles at $95{ }^{\circ} \mathrm{C}$ for $20 \mathrm{~s}, 58-60{ }^{\circ} \mathrm{C}$ for $20 \mathrm{~s}$ and $72{ }^{\circ} \mathrm{C}$ for $20 \mathrm{~s}$ followed 
Table 2 The demographic data of the study subjects.

\begin{tabular}{|c|c|c|c|c|c|}
\hline & PTNL $(n=9)$ & PTL $(n=9)$ & TNL $(n=8)$ & $\mathbf{T L}(n=10)$ & \\
\hline Age & $28(19-36)$ & $26(18-32)$ & $24(16-43)$ & $21(15-44)$ & NS \\
\hline Gravidity & $3(1-4)$ & $4(1-7)$ & $2(1-7)$ & $1(1-5)$ & NS \\
\hline Parity & $1(0-2)$ & $1(0-5)$ & $1(0-2)$ & $0(0-3)$ & NS \\
\hline Race & & & & & PTNL versus TL* \\
\hline African American & 2 & 5 & 4 & 9 & \\
\hline White European & 7 & 4 & 4 & 1 & \\
\hline Gestational age & $32.3(26-35.3)$ & $33.3(26.2-36.3)$ & $38.4(37-39.5)$ & 39.3 (37.3-40.6) & $\begin{array}{l}\mathrm{TL} \text { versus } \mathrm{PTL}^{+} \\
\mathrm{TNL} \text { versus } \mathrm{PTNL}^{+}\end{array}$ \\
\hline Dilatation & $0(0-3.5)$ & $5(1-10)$ & $0(0-3)$ & $6(0.5-10)$ & $\begin{array}{l}\text { TL versus PTL NS } \\
\text { TNL versus PTNL NS }\end{array}$ \\
\hline \multicolumn{6}{|l|}{ Reason for LSCS } \\
\hline FTP & - & - & - & 4 & \\
\hline NRFHT & 3 & 2 & - & 3 & \\
\hline PUS & - & 3 & 6 & 3 & \\
\hline Malpresentation & - & 4 & 1 & - & \\
\hline PET & 4 & - & 1 & - & \\
\hline Placenta praevia & 1 & - & - & - & \\
\hline GDM & 1 & - & - & - & \\
\hline
\end{tabular}

PTNL, preterm no labour; PTL, preterm labour; TNL, term no labour; TL, term labour; FTP, failure to progress; NRFHT, non-reassuring fetal heart trace; PET, pre-eclampsia; GDM, gestational diabetes. ${ }^{*} P<0.05$ and ${ }^{+} P<0.001$.

by an extension at $72{ }^{\circ} \mathrm{C}$ for $15 \mathrm{~s}$. A melt over the temperature range of $72-99{ }^{\circ} \mathrm{C}$ rising by $1^{\circ}$ steps with a wait for $15 \mathrm{~s}$ on the first step followed by a wait of $5 \mathrm{~s}$ for each subsequent step completes the procedure. The cycle at which the fluorescence reached a preset threshold (cycle threshold) was used for quantitative analyses. The cycle threshold in each assay was set at a level where the exponential increase in amplicon abundance was approximately parallel between all the samples. The $r^{2}$ values and efficiencies for the primer pairs are given in Table 3. The mRNA data were expressed relative to the amount of the constitutively expressed housekeeping genes $\beta$-actin and GAPDH for myometrial tissue samples and primary myometrial cell cultures respectively. Different housekeeping genes were used as we have found that in primary uterine myocytes cell culture GAPDH showed less variation and that in myometrial samples $\beta$-actin showed less variation ( $N$ Engineer, SR Sooranna, S Chalkley, L Myatt \& MR Johnson, unpublished observations).

\section{Western analysis}

Myometrial tissues were homogenised in five volumes of a buffer containing 20 mM Tris- $\mathrm{HCl}(\mathrm{pH} 7.4), 150 \mathrm{mM} \mathrm{NaCl}, 1 \%$ Triton X-100, $1 \mathrm{mM}$ EDTA, $1 \mathrm{mM}$ EGTA, $2.5 \mathrm{mM}$ sodium pyrophosphate, $1 \mathrm{mM} \beta$-glycerophosphate, $2 \mathrm{mM}$ dithiotreitol, $1 \mathrm{mM} \mathrm{Na} \mathrm{VO}_{4}, 1 \mathrm{mM}$ phenylmethylsulphonyl fluoride and $1 \mu \mathrm{g} / \mathrm{ml}$ leupeptin. After centrifugation for $1 \mathrm{~min}$ at $12000 \mathrm{~g}$, homogenates were aliquoted and frozen at $-80{ }^{\circ} \mathrm{C}$. Protein concentrations were determined by Protein assay (Bio-Rad Laboratories) and BSA reference standards. Electrophoresis was carried out using $15 \mu \mathrm{g}$ aliquots of protein samples in $2 \times$ loading buffer (4\% SDS, 20\% glycerol, 10\% 2-mercaptoethanol, $0.004 \%$ bromophenol blue and $0.125 \mathrm{~mol} / \mathrm{l}$ Tris$\mathrm{HCl}$, pH 6.8). Samples were boiled for $5 \mathrm{~min}$, quenched on ice and subsequently run on precast $10 \%$ SDS-polyacrylamide gels (Bio-Rad Laboratories).

Western blotting was carried out following electrophoretic transfer in $25 \mathrm{mmol} / \mathrm{I}$ Tris $(\mathrm{pH} \mathrm{8.3),} 192 \mathrm{mmol} / \mathrm{l}$ glycine and
$20 \% \mathrm{v} / \mathrm{v}$ methanol on to Hybond ECL nitrocellulose membrane (Amersham Life Science). Membranes were blocked in 5\% milk protein in $0.1 \%$ Tween-PBS for $1 \mathrm{~h}$ at room temperature. Mouse MAB to $\beta$-actin was purchased from Sigma-Aldrich Co. Ltd and goat polyclonal antibodies to OXTR (two antibodies, one directed to the $\mathrm{C}$-terminus and the other to the $\mathrm{N}$-terminus) CX-43 (both phospho and non-phospho forms) were purchased from Santa Cruz Biotechnology Inc. (Santa Cruz, CA, USA). Polyclonal antibody against human PGHS-2 was purchased from Cayman Chemical (Ann Arbor, MI, USA). Specific rabbit polyclonal antibodies directed against the phospho- or total CX-43 (New England Biolabs Ltd, Hitchin, UK). The antibodies were used at a dilution of 1:1000 and incubated overnight at $4{ }^{\circ} \mathrm{C}$. Membranes were washed with $0.1 \%$ Tween-PBS and then incubated with anti-goat immunoglobulin G-horseradish peroxidase secondary antibody at a dilution of $1: 2000$ for $1 \mathrm{~h}$ at room temperature. ECL Western blotting detection was carried out using standard protocols (Amersham Life Science). Protein band size was determined using Rainbow coloured protein molecular weight markers (Amersham Life Science). Antibody specificity was confirmed using positive controls. Exposure of cells to u.v. B irradiation (wavelength $356 \mathrm{~nm}$ ) for 30 min was used as a positive control. Western autoradiographs were quantified by digital densitometry using the Image Master VDS gel documentation system and Image Master VDS Software (Amersham Life Science). Protein bands were digitised, ensuring that the range of pixel densities did not extend to either the minimum or maximum values. Mean pixel density for each band was assessed using a sample gate of the same size. To allow comparisons between blots prepared on different occasions, a single control sample was included on each blot. Final pixel density was adjusted to ensure that this control sample carried the same value for each blot.

\section{Cell culture}

Biopsies $\left(0.5 \mathrm{~cm}^{3}\right)$ of term human myometrium were collected at the time of caesarean section (LSCS) from women not in 


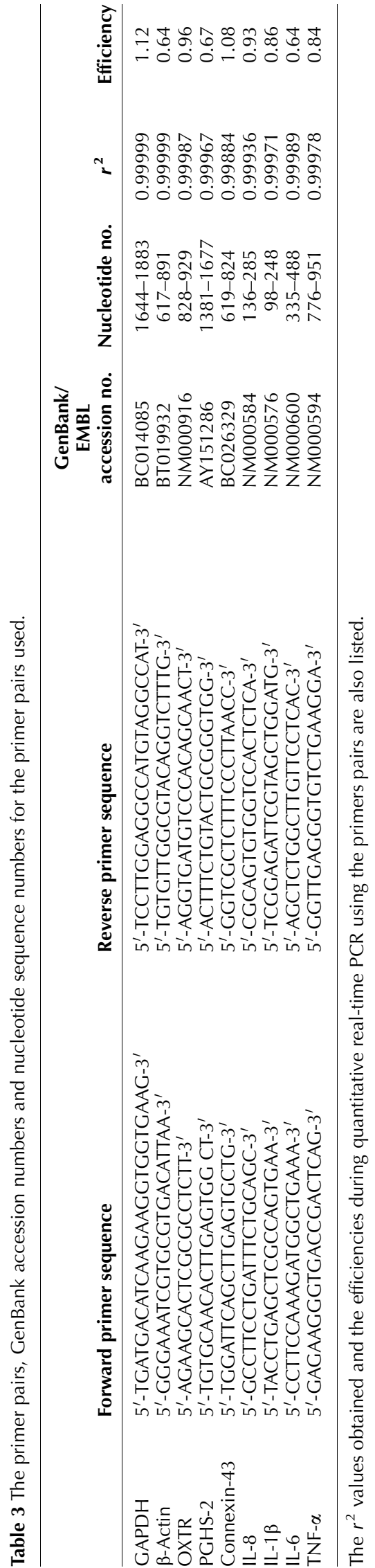

labour and stored in DMEM containing $100 \mathrm{mU} / \mathrm{ml}$ penicillin and $100 \mu \mathrm{g} / \mathrm{ml}$ streptomycin. Samples were stored at $4{ }^{\circ} \mathrm{C}$ for no more than $3 \mathrm{~h}$ prior to cell preparation for culture. The indications for LSCS in this group of women were previous LSCS, breech presentation and maternal request. All specimens were obtained after patient consent, and the Riverside Research Ethics Committee approved the study.

Primary human uterine myocytes were isolated using a mixture of collagenases and cultured in DMEM $7.5 \%$ fetal calf serum (FCS), 100 munits/ml penicillin and $100100 \mu \mathrm{g} / \mathrm{ml}$ streptomycin in $\mathrm{T} 75$ in an atmosphere of $5 \% \mathrm{CO}_{2}: 95 \%$ air at $37^{\circ} \mathrm{C}$ (Sooranna et al. 2005). Myometrial cells grown in this manner have previously been characterised (Sooranna et al. 2005). Cells from passages 1 to 4 were trypsinised in $0.25 \%$ trypsin containing $0.02 \%$ EDTA in PBS and cultured in 6-well plates. When cells were $80-90 \%$ confluent (days 3-4), old medium was removed and replaced with $1.5 \mathrm{ml}$ fresh medium supplemented with $7.5 \mathrm{mM}$ HEPES with $1 \%$ FCS overnight. After 16-18 h, cells were

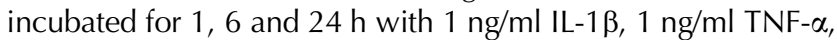
$1 \mathrm{ng} / \mathrm{ml} \mathrm{IL-6,} 1 \mathrm{ng} / \mathrm{ml} \mathrm{IL-8,} 10 \mathrm{nMPGE}_{2}, 10 \mathrm{nM} \mathrm{PGF}_{2 \alpha}$ or $100 \mathrm{nM}$ OXT after which media was removed and cells frozen in liquid nitrogen and stored at $-80{ }^{\circ} \mathrm{C}$ until extraction of RNA.

\section{Statistical analysis}

Demographic data were analysed using the Mann-Whitney $U$ test for continuously distributed data and a Fisher's exact test for categorical data as appropriate. The myometrial data were not normally distributed and were expressed as median and range. The data were analyzed with a Kruskall-Wallis test and posttesting with Mann-Whitney $U$ test for independent samples. The effect of gestational age on gene expression was assessed using a Spearman test for non-parametric data. Multiple regression analysis was used to assess whether there was any relationship between individual gene expression, gestational age, labour status and site of tissue biopsy (upper or lower segment). In cell culture studies, the data were not normally distributed and were expressed as median and range. The data were analyzed with a Friedman test (non-parametric repeated measures ANOVA) and post-testing with Mann-Whitney $U$ test.

\section{Acknowledgements}

The study was supported in part by a grant from Wellbeing. The authors declare that there is no conflict of interest that would prejudice the impartiality of this scientific work.

\section{References}

Aguan K, Carvajal JA, Thompson LP \& Weiner CP 2000 Application of a functional genomics approach to identify differentially expressed genes in human myometrium during pregnancy and labour. Molecular Human Reproduction 6 1141-1145.

Allport VC, Pieber D, Slater DM, Newton R, White JO \& Bennett PR 2001 Human labour is associated with nuclear factor- $\mathrm{B} B$ activity which mediates cyclo-oxygenase- 2 expression and is involved with the 'functional progesterone withdrawal'. Molecular Human Reproduction $7581-586$. 
Astle S, Newton R, Thornton S, Vatish M \& Slater DM 2007 Expression and regulation of prostaglandin $\mathrm{E}$ synthase isoforms in human myometrium with labour. Molecular Human Reproduction 13 69-75.

Blanks AM, Vatish M, Allen MJ, Ladds G, de Wit NC, Slater DM \& Thornton S 2003 Paracrine oxytocin and estradiol demonstrate a spatial increase in human intrauterine tissues with labor. Journal of Clinical Endocrinology and Metabolism 88 3392-3400.

Brennecke SP, Castle BM, Demers LM \& Turnbull AC 1985 Maternal plasma prostaglandin E2 metabolite levels during human pregnancy and parturition. British Journal of Obstetrics and Gynaecology 92 345-349.

Bukowski R, Hankins GD, Saade GR, Anderson GD \& Thornton S 2006 Labor-associated gene expression in the human uterine fundus, lower segment, and cervix. PLoS Medicine 3 e169.

Chan EC, Fraser S, Yin S, Yeo G, Kwek K, Fairclough RJ \& Smith R 2002 Human myometrial genes are differentially expressed in labor: a suppression subtractive hybridization study. Journal of Clinical Endocrinology and Metabolism 87 2435-2441.

Charpigny G, Leroy MJ, Breuiller-Fouche M, Tanfin Z, Mhaouty-Kodja S, Robin P, Leiber D, Cohen-Tannoudji J, Cabrol D, Barberis C et al. 2003 A functional genomic study to identify differential gene expression in the preterm and term human myometrium. Biology of Reproduction $\mathbf{6 8}$ 2289-2296.

Chow L \& Lye SJ 1994 Expression of the gap junction protein connexin-43 is increased in the human myometrium toward term and with the onset of labor. American Journal of Obstetrics and Gynecology 170 788-795.

Cluff AH, Bystrom B, Klimaviciute A, Dahlqvist C, Cebers G, Malmstrom A \& Ekman-Ordeberg G 2006 Prolonged labour associated with lower expression of syndecan 3 and connexin 43 in human uterine tissue. Reproductive Biology and Endocrinology 424.

Condon JC, Jeyasuria P, Faust JM, Wilson JW \& Mendelson CR 2003 A decline in the levels of progesterone receptor coactivators in the pregnant uterus at term may antagonize progesterone receptor function and contribute to the initiation of parturition. PNAS 100 9518-9523.

Cook JL, Zaragoza DB, Sung DH \& Olson DM 2000 Expression of myometrial activation and stimulation genes in a mouse model of preterm labor: myometrial activation, stimulation, and preterm labor. Endocrinology 141 1718-1728.

Doring B, Shynlova O, Tsui P, Eckardt D, Janssen-Bienhold U, Hofmann F, Feil S, Feil R, Lye SJ \& Willecke K 2006 Ablation of connexin43 in uterine smooth muscle cells of the mouse causes delayed parturition. Journal of Cell Science 119 1715-1722.

Elliott CL, Slater DM, Dennes W, Poston L \& Bennett PR 2000 Interleukin 8 expression in human myometrium: changes in relation to labor onset and with gestational age. American Journal of Reproductive Immunology 43 272-277.

Esplin MS, Fausett MB, Peltier MR, Hamblin S, Silver RM, Branch DW, Adashi EY \& Whiting D 2005 The use of CDNA microarray to identify differentially expressed labor-associated genes within the human myometrium during labor. American Journal of Obstetrics and Gynecology 193 404-413.

Fuchs AR, Periyasamy S, Alexandrova M \& Soloff MS 1983 Correlation between oxytocin receptor concentration and responsiveness to oxytocin in pregnant rat myometrium: effects of ovarian steroids. Endocrinology $113742-749$.

Fuchs AR, Fuchs F, Husslein P \& Soloff MS 1984 Oxytocin receptors in the human uterus during pregnancy and parturition. American Journal of Obstetrics and Gynecology 150 734-741.

Havelock JC, Keller P, Muleba N, Mayhew BA, Casey BM, Rainey WE \& Word RA 2005 Human myometrial gene expression before and during parturition. Biology of Reproduction 72 707-719.

Helmer H, Tretzmuller U, Brunbauer M, Kaider A, Husslein P \& Knofler M 2002 Production of oxytocin receptor and cytokines in primary uterine smooth muscle cells cultivated under inflammatory conditions. Journal of the Society of Gynecological Investigation 9 15-21.

Hirsch E, Filipovich Y \& Mahendroo M 2006 Signaling via the type I IL-1 and TNF receptors is necessary for bacterially induced preterm labor in a murine model. American Journal of Obstetrics and Gynecology 194 1334-1340.

Keski-Nisula L, Aalto ML, Katila ML \& Kirkinen P 2000 Intrauterine inflammation at term: a histopathologic study. Human Pathology 31 841-846.
Khatun S, Kanayama N, Md Belayet H, Yonezawa M, Kobayashi T \& Terao T 1999 Interleukin-8 potentiates the effect of interleukin-1-induced uterine contractions. Human Reproduction 14 560-565.

Kimura T, Takemura $M$, Nomura $S$, Nobunaga $T$, Kubota $Y$, Inoue $T$, Hashimoto K, Kumazawa I, Ito Y, Ohashi K et al. 1996 Expression of oxytocin receptor in human pregnant myometrium. Endocrinology 137 780-785.

Loudon JA, Sooranna SR, Bennett PR \& Johnson MR 2004 Mechanical stretch of human uterine smooth muscle cells increases IL-8 mRNA expression and peptide synthesis. Molecular Human Reproduction 10 895-899.

Lye SJ, Nicholson BJ, Mascarenhas M, MacKenzie L \& Petrocelli T 1993 Increased expression of connexin-43 in the rat myometrium during labor is associated with an increase in the plasma estrogen:progesterone ratio. Endocrinology 132 2380-2386.

Maul H, Nagel S, Welsch G, Schafer A, Winkler M \& Rath W 2002 Messenger ribonucleic acid levels of interleukin-1 beta, interleukin-6 and interleukin-8 in the lower uterine segment increased significantly at final cervical dilatation during term parturition, while those of tumor necrosis factor alpha remained unchanged. European Journal of Obstetrics, Gynecology, and Reproductive Biology 102 143-147.

McNutt CM, Nicholson BJ \& Lye SJ 1994 ACTH-induced preterm labour in the ewe is associated with increased mRNA and protein levels of myometrial gap junction protein, connexin-43. Journal of Endocrinology 141 195-202.

Mesiano S, Chan EC, Fitter JT, Kwek K, Yeo G \& Smith R 2002 Progesterone withdrawal and estrogen activation in human parturition are coordinated by progesterone receptor A expression in the myometrium. Journal of Clinical Endocrinology and Metabolism 87 2924-2930.

Osman I, Young A, Ledingham MA, Thomson AJ, Jordan F, Greer IA \& Norman JE 2003 Leukocyte density and pro-inflammatory cytokine expression in human fetal membranes, decidua, cervix and myometrium before and during labour at term. Molecular Human Reproduction 9 41-45.

Osmers RG, Adelmann-Grill BC, Rath W, Stuhlsatz HW, Tschesche H \& Kuhn W 1995 Biochemical events in cervical ripening dilatation during pregnancy and parturition. Journal of Obstetrics and Gynaecology 21 185-194.

Ou CW, Orsino A \& Lye SJ 1997 Expression of connexin-43 and connexin26 in the rat myometrium during pregnancy and labor is differentially regulated by mechanical and hormonal signals. Endocrinology 138 5398-5407.

Phaneuf S, Rodriguez Linares B, TambyRaja RL, MacKenzie IZ \& Lopez Bernal A 2000 Loss of myometrial oxytocin receptors during oxytocininduced and oxytocin-augmented labour. Journal of Reproduction and Fertility 120 91-97.

Pierce BT, Calhoun BC, Adolphson KR, Lau AF \& Pierce LM 2002 Connexin 43 expression in normal versus dysfunctional labor. American Journal of Obstetrics and Gynecology 186 504-511.

Rezapour M, Kilarski WM, Severs NJ, Gourdie RG, Rothery S, Backstrom T, Roomans GM \& Ulmsten U 1997 Quantitative immunoconfocal analysis of human myometrial gap junction connexin 43 in relation to steroid hormone concentrations at term labour. Human Reproduction 12 159-166.

Risek B, Guthrie S, Kumar N \& Gilula NB 1990 Modulation of gap junction transcript and protein expression during pregnancy in the rat. Journal of Cell Biology 110 269-282.

Romero R, Baumann P, Gonzalez R, Gomez R, Rittenhouse L, Behnke E \& Mitchell MD 1994 Amniotic fluid prostanoid concentrations increase early during the course of spontaneous labor at term. American Journal of Obstetrics and Gynecology 171 1613-1620.

Sadowsky DW, Adams KM, Gravett MG, Witkin SS \& Novy MJ 2006 Preterm labor is induced by intraamniotic infusions of interleukin-1 $\beta$ and tumor necrosis factor-alpha but not by interleukin- 6 or interleukin-8 in a nonhuman primate model. American Journal of Obstetrics and Gynecology 195 1578-1589.

Schmid B, Wong S \& Mitchell BF 2001 Transcriptional regulation of oxytocin receptor by interleukin-1 $\beta$ and interleukin-6. Endocrinology 142 1380-1385.

Sellers SM, Mitchell MD, Bibby JG, Anderson AB \& Turnbull AC 1981 A comparison of plasma prostaglandin levels in term and preterm labour. British Journal of Obstetrics and Gynaecology 88 362-366.

Skinner KA \& Challis JR 1985 Changes in the synthesis and metabolism of prostaglandins by human fetal membranes and decidua at labor. American Journal of Obstetrics and Gynecology 151 519-523. 
Soloff MS, Alexandrova M \& Fernstrom MJ 1979 Oxytocin receptors: triggers for parturition and lactation? Science 204 1313-1315.

Soloff MS, Izban MG, Cook DL Jr, Jeng YJ \& Mifflin RC 2006 Interleukin-1induced NF- $\mathrm{KB}$ recruitment to the oxytocin receptor gene inhibits RNA polymerase II-promoter interactions in cultured human myometrial cells. Molecular Human Reproduction 12 619-624.

Sooranna SR, Lee Y, Kim LU, Mohan AR, Bennett PR \& Johnson MR 2004 Mechanical stretch activates type 2 cyclooxygenase via activator protein1 transcription factor in human myometrial cells. Molecular Human Reproduction 10 109-113.

Sooranna SR, Engineer N, Loudon JA, Terzidou V, Bennett PR \& Johnson MR 2005 The mitogen-activated protein kinase dependent expression of prostaglandin $\mathrm{H}$ synthase-2 and interleukin-8 messenger ribonucleic acid by myometrial cells: the differential effect of stretch and interleukin13. Journal of Clinical Endocrinology and Metabolism 90 3517-3527.

Sooranna SR, Grigsby PL, Engineer N, Liang Z, Sun K, Myatt L \& Johnson MR 2006 Myometrial prostaglandin E2 synthetic enzyme mRNA expression: spatial and temporal variations with pregnancy and labour. Molecular Human Reproduction 12 625-631.

Sparey C, Robson SC, Bailey J, Lyall F \& Europe-Finner GN 1999 The differential expression of myometrial connexin-43, cyclooxygenase-1 and -2 , and Gs alpha proteins in the upper and lower segments of the human uterus during pregnancy and labor. Journal of Clinical Endocrinology and Metabolism 84 1705-1710.

Strakova Z, Copland JA, Lolait SJ \& Soloff MS 1998 ERK2 mediates oxytocin-stimulated PGE2 synthesis. American Journal of Physiology 274 E634-E641.
Terzidou V, Sooranna SR, Kim LU, Thornton S, Bennett PR \& Johnson MR 2005 Mechanical stretch up-regulates the human oxytocin receptor in primary human uterine myocytes. Journal of Clinical Endocrinology and Metabolism 90 237-246.

Thomson AJ, Telfer JF, Young A, Campbell S, Stewart CJ, Cameron IT, Greer IA \& Norman JE 1999 Leukocytes infiltrate the myometrium during human parturition: further evidence that labour is an inflammatory process. Human Reproduction 14 229-236.

Turnbull AC, Anderson AB, Flint AP, Jeremy JY, Keirse MJ \& Mitchell MD 1977 Human parturition. Ciba Foundation Symposia 47 427-459.

Wathes DC, Borwick SC, Timmons PM, Leung ST \& Thornton S 1999 Oxytocin receptor expression in human term and preterm gestational tissues prior to and following the onset of labour. Journal of Endocrinology 161 143-151.

Winkler M, Fischer DC, Ruck P, Marx T, Kaiserling E, Oberpichler A, Tschesche H \& Rath W 1999 Parturition at term: parallel increases in interleukin- 8 and proteinase concentrations and neutrophil count in the lower uterine segment. Human Reproduction 14 1096-1100.

Received 2 October 2007

First decision 19 November 2007

Accepted 3 January 2008 